\title{
E. COLI AND ENTEROCOCCI LEVELS IN URBAN STORMWATER, RIVER WATER AND CHLORINATED TREATMENT PLANT EFFLUENT
}

\author{
John J. Gannon and Michael K. Busse \\ Department of Environmental and Industrial Health, School of Public Health, \\ The University of Michigan, Ann Arbor, MI 48109, U.S.A.
}

(First received July 1988; accepted in revised form March 1989)

\begin{abstract}
Stormwater from the Ann Arbor, Michigan area affects the bacterial indicator organism quality of the Huron River. Investigations during the 1985 summer period involved sampling during dry and wet periods with parallel determination on each sample for fecal coliforms, fecal streptococci, $E$. coli and enterococci. Wet weather bacterial indicator densities were statistically significantly higher than dry weather levels, and downstream densities were statistically significantly higher than upstream densities. The FC/FS (fecal coliforms/fecal streptococci) ratios for the storm drains were low and suggestive of more animal than human sources. The geometric mean $\mathrm{EC} / \mathrm{FC}(E$. coli /fecal coliforms) ratios were in the range of $0.82-1.34$, well above the ratio of 0.63 calculated using the U.S. EPA recommended level for $E$. coli of $126 / 100 \mathrm{ml}$ to the presently accepted level for fecal coliforms of $200 / 100 \mathrm{ml}$. If the intent is to maintain the currently accepted illness rate, additional results from other areas are necessary to refine the $E$. coli and enterococci levels for water quality standard development purposes. In general, physical-chemical observations reflected the source of the sample.
\end{abstract}

Key words-indicator bacteria, urban runoff, E. coli, enterococci, water quality, wastewater, stormwater

\section{INTRODUCTION}

Urban stormwater impacts the ambient bacteriological quality of the Huron River downstream from separate storm drains in the Ann Arbor, Michigan, area. Particular concern existed about the use of a downstream river impoundment for windsurfing. Existing sampling was conducted during the 1985 summer recreational season to evaluate the impact on the river water quality of discharges from these drains, during both dry weather and wet weather periods.

The U.S. EPA (1986a) concluded that the indicator organism group, the fetal coliforms, is inadequate, and recommended instead the use of either $E$. coli or enterococci as a bacterial indicator to evaluate ambient fresh water quality. They further recommended densities for $E$. coli not to exceed a geometric mean of $126 / 100 \mathrm{ml}$, or densities for enterococci not to exceed a geometric mean of $33 / 100 \mathrm{ml}$ to provide for the protection of primary water contact recreation. The selection of these indicator organisms and the associated levels is based on the work of Dufour (1984) and Cabelli (1983) relating mean bacterial indicator densities to gastrointestinal illness rates in bathers. It is intended that the new organisms would replace the present fecal coliform standard of a geometric mean of $200 / 100 \mathrm{ml}$.

The present study involved parallel determinations on each sample for total coliforms, fecal coliforms, fecal streptococci, $E$. coli and enterococci. In addition, samples of the effluent from the Ann Arbor, Michigan tertiary wastewater treatment plant, which discharges chlorinated effluent downstream of the study area, were collected on a number of occasions that the storm drains and river were sampled. Thus, a comparison of indicator organism levels is possible for urban stormwater, subsequent downstream river conditions, and chlorinated wastewater treatment plant effluent.

Allen Drain, one of the main drains in the study area, has been reported on by several investigators including Burm and Vaughan (1966), Benzie and Courchaine (1966), Collins and Ridgeway (1980) and, more recently, by Schmidt and Spencer (1986) and Schillinger and Gannon (1985). Also, Geldreich et al. (1968) and Olivieri (1977) have presented material on the bacteriological aspects of stormwater pollution. Others have reported on recreational water quality including Henderson (1968), Foster et al. (1971), Vasconcelos and Anthony (1985) and Geldreich (1970).

\section{STUDY AREA}

Figure 1 shows the survey area involving the Huron River flowing through Ann Arbor, Michigan starting at Maple Road upstream of the City and extending to Geddes Dam downstream of the City. The main impact is Gallup Park located on Geddes Impoundment downstream of the Allen, Traver Creek, Fuller and North Campus storm drains. The Huron River is a tributary of Lake Erie, with a drainage area of $1888 \mathrm{~km}^{2}$ (729 sq. miles) at the U.S. Geological stream gage on the river located below the Allen Drain discharge. 


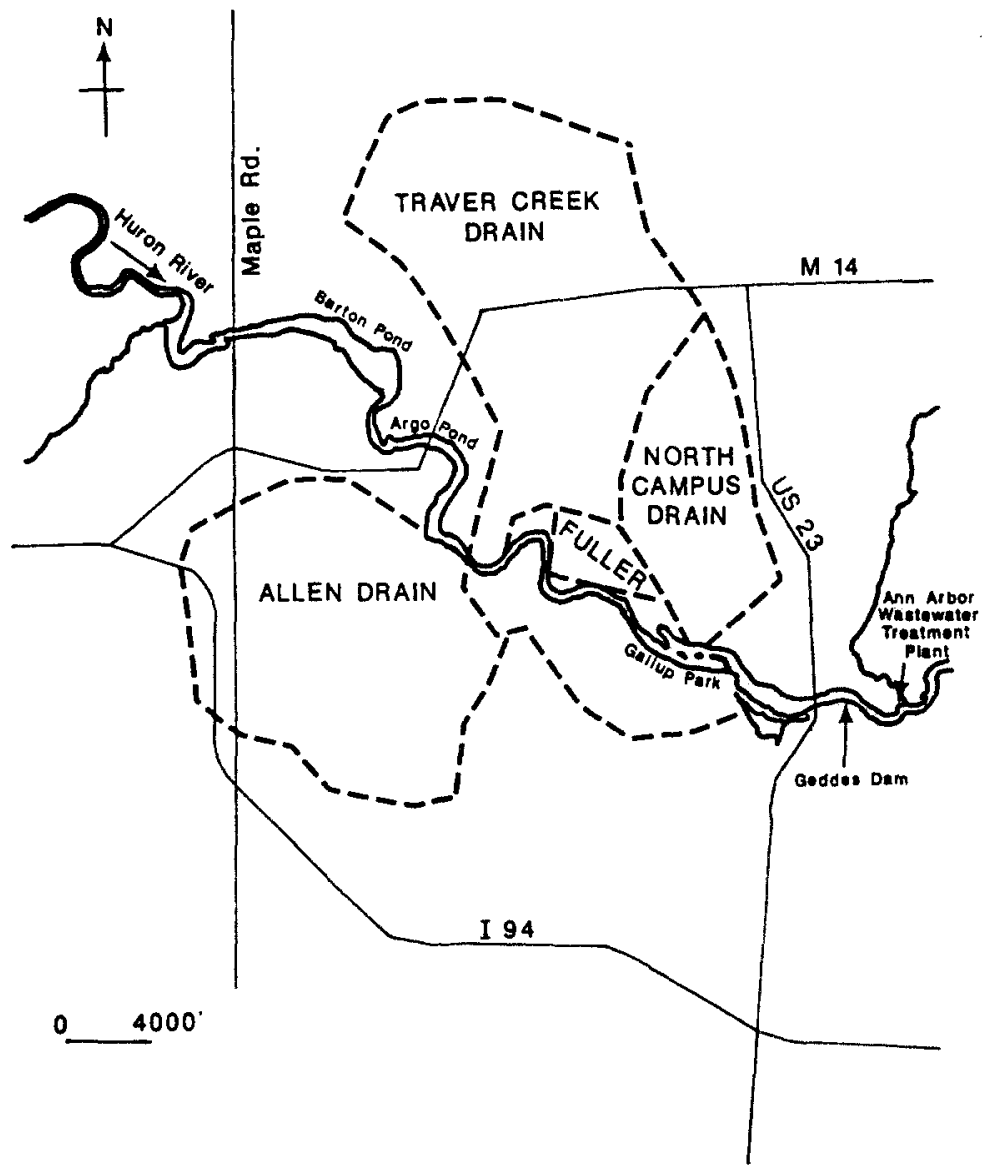

Fig. 1. Drainage areas of major storm drains in the Ann Arbor, Michigan area upstream of Gallup Park, the Huron River.

Allen Drain (Wastenaw County, Mich. 1981) is almost completely enclosed with the majority of its $15,378,220 \mathrm{~m}^{2}$ (3800 acres) within the City of Ann Arbor. Land use in this area is $73 \%$ residential, $17 \%$ commercial and $10 \%$ undeveloped. Traver Creek watershed covers approx. $18,478,145 \mathrm{~m}^{2}(4,566$ acres) with $67 \%$ of the land undeveloped, $31 \%$ residential and $2 \%$ commercial. Fuller Drain covers a small part of the University of Michigan North Campus. The North Campus Drain has a watershed of $6,357,680 \mathrm{~m}^{2}(1571$ acres), with $62 \%$ of the land area undeveloped, $34 \%$ residential and $4 \%$ commercial. It discharges directly into the Gallup Park area.

Operation of the gates on the dams of two upstream river impoundments, Barton and Argo Ponds, significantly influenced the river flow into Gallup Park on an hourly basis during the 1985 summer period. As a result, meaningful mass balance calculations have not been possible.

\section{PROCEDURES}

The strategy of the field sampling was to sample during and following precipitation. In addition, the plan called for at least a once a week sampling interval, with a goal of at least one wet weather event per month. As it turned out, this goal was exceeded because of above average precipitation, particularly during July and August. The minimum weekly sampling interval also provided for dry weather observations. Increased attention was given to the Gallup Park area which involved additional sampling for 1 and 2 days following each wet weather effort. Thirteen sites were routinely sampled which included main river locations, the outlet from each of the major storm drains, and the effluent from the Ann Arbor, Michigan wastewater treatment plant.

Field processing included water temperature measurement and dissolved oxygen fixation, while laboratory analyses included: $E$. coli (membrane filter), fecal coliforms (membrane filter), total coliforms (membrane filter), fecal streptococci (membrane filter), enterococci (membrane filter), conductivity, $\mathrm{pH}$, turbidity, total solids and suspended solids. Procedures recommended by Standard Methods (APHA, 1985) were employed in all cases, with the exception of $E$. coli (U.S. EPA, 1985; Dufour et al., 1981) and enterococci (U.S. EPA, 1985; Levin et al., 1975) procedures which were recommended by the U.S. EPA. Sodium thiosulfate was included in the containers used to sample the chlorinated effluent of the Ann Arbor wastewater plant to neutralize any chlorine present in the effluent. All bacteriological samples were placed immediately after collection in an insulated chest containing a coolant for transport to a nearby laboratory, where they were processed upon receipt, with no sample held longer than $6 \mathrm{~h}$ from the time of collection to the time of processing.

The MIDAS statistical program, available on the University of Michigan computing facility, was used for data summary and analysis. Specific procedures have been docu- 
mented by Fox and Guire (1976), and the staff of the Statistical Research Laboratory, The University of Michigan (1976). Primary reliance has been on Student's $t$ - and $F$-tests for comparing two sets of data. In a few instances where the $F$-test indicated the Student test to be inappropriate, the Mann-Whitney and the median tests were used. The lognormal distribution ( $\log _{10}$ transformation) was found to best describe the variation of the bacterial indicator organisms, and it has been used in all summaries and tests for statistical significance. On the other hand, the normal distribution was found to best describe the variation of the physical-chemical data, and it has been used to summarize and test this data. Various statistical procedures were used to test the normality of these respective distributions. Primary reliance was on normal and lognormal probability plots generated using the MIDAS statistical program, with data plots approximating a straight line as the main criteria for accepting the normality of the distribution. Velz (1984) and Gannon (1959) have used similar procedures for data summary and normality testing.

\section{RESULTS AND DISCUSSION}

Sampling was conducted during the period 6 May 1985-10 September 1985. Indicator organism levels are summarized in Table 1 in terms of the Barton -Argo upstream area involving three river stations together, the mouth of each major storm drain including Allen, Traver, Fuller and North Campus, the Gallup Park downstream area involving three river stations together, and the Ann Arbor Wastewater Treatment Plant effluent. Also, the results are separated according to dry periods and wet periods, with the wet periods defined as times when the precipitation was greater than $0.25 \mathrm{~cm} /$ day $(0.1$ in./day). Nineteen separate rain events were sampled in 1985 at most stations, with the daily average precipitation ranging from $0.33 \mathrm{~cm} /$ day $(0.13$ in./

Table 1. Bacterial indicator densities 1985

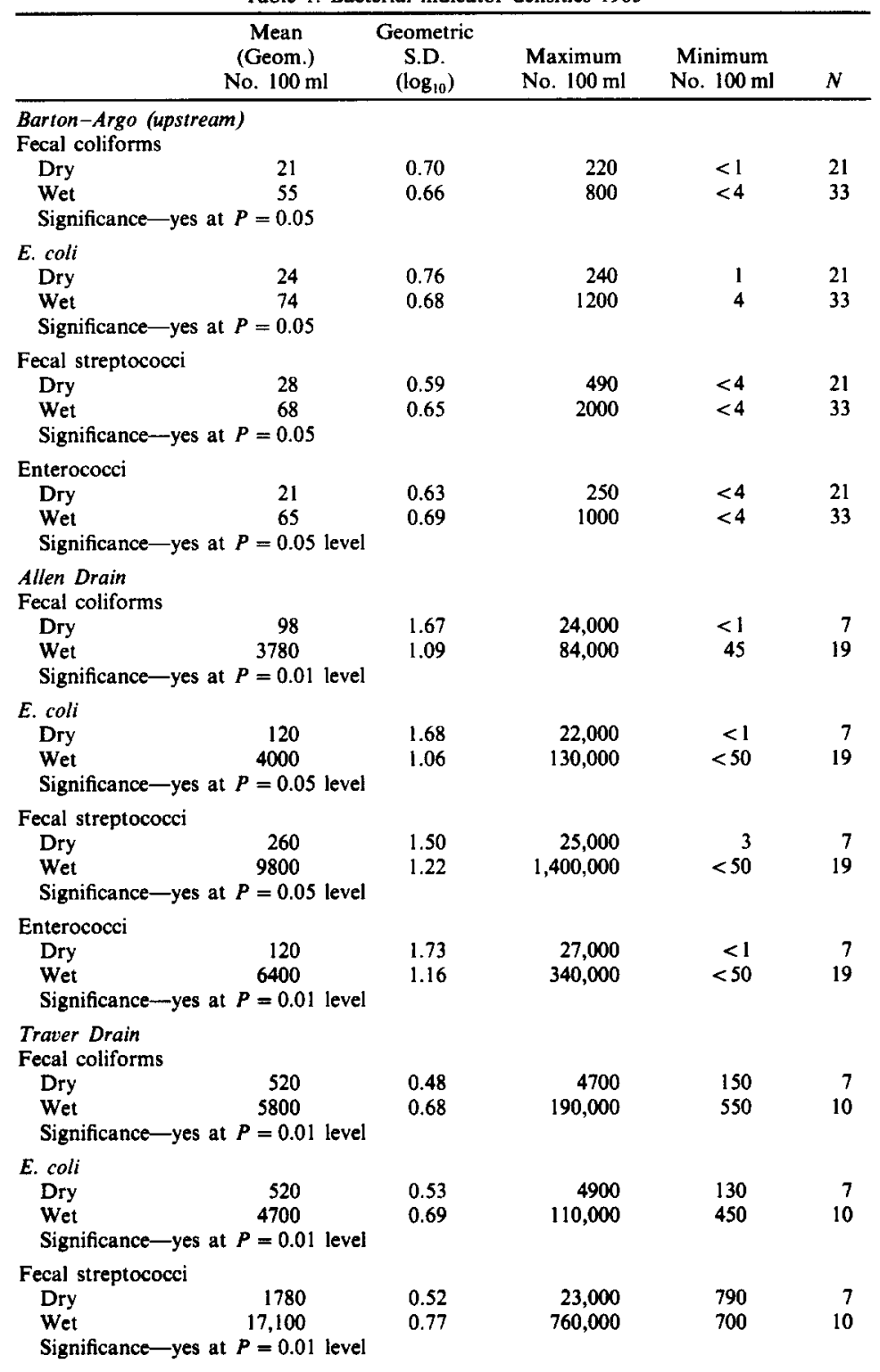


Table 1-continued

\begin{tabular}{lccccc}
\hline & $\begin{array}{c}\text { Mean } \\
(\text { Geom.) } \\
\text { No. } 100 \mathrm{ml}\end{array}$ & $\begin{array}{c}\text { Geometric } \\
\text { S.D. } \\
\left(\log _{10}\right)\end{array}$ & $\begin{array}{c}\text { Maximum } \\
\text { No. } 100 \mathrm{ml}\end{array}$ & $\begin{array}{c}\text { Minimum } \\
\text { No. } 100 \mathrm{ml}\end{array}$ & $N$ \\
\hline Enterococci & 1550 & 0.45 & 13,000 & 700 & 7 \\
$\begin{array}{l}\text { Dry } \\
\text { Wet }\end{array}$ & 10,800 & 0.75 & 80,000 & 150 & 10 \\
Significance-yes at $P=0.05$ level & & & &
\end{tabular}

$P=0.05$ level

Fuller Drain

Fecal coliforms

$\begin{array}{lll}\text { Dry } & 3 & 0.43\end{array}$

$\begin{array}{lll}\text { Wet } & 15 & 1.01\end{array}$

Significance-not significant $(P>0.05)$

E. coli

$\begin{array}{lrr}\text { Dry } & 4 & 0.45 \\ \text { Wet } & 16 & 0.98\end{array}$

Significance--not significant $(P>0.05)$

Fecal streptococci

$\begin{array}{lcr}\text { Dry } & 6 & 0.42 \\ \text { Wet } & 29 & 1.18 \\ \text { Significance-not significant } & (P>0.05)\end{array}$

Enterococci

Dry

Wet

Significance-not significant $(P>0.05)$

1.11

North Campus Drain

Fecal coliformis

Dry

Wet $\quad 3900$

520
3900

Significance-yes at $P=0.01$ level

0.17

0.36

E. coli

Dry

550

$\begin{array}{lc}\text { Wet } & 3900 \\ \text { Significance-yes at } P=0.01 & \text { level }\end{array}$

0.28

0.33

Fecal streptococci

Dry

700

0.17

Significance-yes at $P=0.01$ level

0.50

Significance-

Dry

790

9100

0.45
0.45

Significance-yes at $P=0.0 \mathrm{I}$ level

Gallup Park (downstream)

Fecal coliforms

Dry

88

Wet

610

0.33

0.76

Significance-yes at $P=0.01$ level

E. coli

Dry

80

540

0.34

0.71

10
1600

$<1$

$<2$

10

1100

$<1 \quad 7$

Significance-yes at $P=0.01$ level

Fecal streptococci

Dry

Wet $\quad 380$

$58 \quad 0.40$

Significance-yes at $P=0.01$ level

0.90

Enterococci

Dry

42

0.49

Wet

300

0.95

Significance--yes at $P=0.0 \mathrm{I}$ leve

Ann Arbor wastewater effuent

Fecal coliforms

Dry

Wet

$\begin{array}{ll}27 & 0.71 \\ 74 & 0.75\end{array}$

Significance-not significant $(P>0.05)$

E. coli

Dry

$25 \quad 0.66$

0.65

Significance-not significant $(P>0.05)$

Fecal streptococci

\begin{tabular}{lcrrrr} 
Dry & 34 & 0.47 & 170 & 8 & 7 \\
Wet & 87 & 0.63 & 890 & 10 & 9 \\
Significance-not significant $(P>0.05)$ & & & & \\
Enterococei & & & & \\
Dry & 39 & 0.41 & 140 & $<10$ & 7 \\
Wet & 57 & 0.60 & 310 & 8 & 9 \\
Significance-not significant $(P>0.05)$ & & & \\
\hline
\end{tabular}


day) to $4.84 \mathrm{~cm} /$ day (1.59 in./day). Gannon (1988) reported on the development of a model relating precipitation rate to resulting fecal coliforms level in the Gallup Park area. This model is in use as a short-term management tool to alert the public to times when fecal coliforms are predicted to exceed current State of Michigan water quality standards.

The first column in Table 1 is the geometric mean value for the various bacterial indicator densities and is expressed in number of organisms per $100 \mathrm{ml}$. The second column is labeled as the geometric standard deviation and is expressed in $\log _{10}$ units.

Fuller Drain presented an unusual condition of very low indicator organism levels in comparison to the other drains. A special study was conducted on 24 October 1985 following 0.1 in. of precipitation, at which time a significant residual chlorine was measured at the mouth of the drain. The source of this chlorine is not known, but the Fuller Drain indicator bacteria levels must be viewed cautiously in the light of this observation.

Statistical significance conclusions between wet and dry bacterial indicator densities are presented in Table 1. Significance levels at $P=0.01$ and $P=0.05$ and a no significance level of $P>0.05$ are indicated. It is apparent that the wet weather levels are statistically significantly higher than the dry weather levels at all river and storm drain outlets, except for Fuller Drain and the Ann Arbor wastewater treatment plant effluent.

The geometric mean level for all indicator organisms is higher at Gallup Park than at Barton-Argo reflecting discharges from the urban storm drains. A statistically significant difference was demonstrated at $P=0.05$ and at a lower $P$ during wet periods. Traver, North Campus and Allen Drains all have indicator bacteria levels above the nearby river stations, which in turn are higher than the Ann Arbor wastewater treatment plant effluent. Also, it is apparent this effluent is approximately the same level as the upstream Barton-Argo stations. No statistical significance $(P>0.05)$ in the levels at Barton-Argo and the Ann Arbor wastewater effluent was found.

The storm drains (except Fuller) have much higher bacterial levels and also a greater impact on the Gallup Park area during wet periods over dry periods. This results not only from higher bacterial levels in the storm drains, but also from much higher storm drain water discharges during wet periods. Fecal coliforms as high as $41,000 / 100 \mathrm{ml}$ were measured on occasion in the Gallup Park area.

Indicator organism ratios including FC/FS (fecal coliforms/fecal streptococci), EC/FC (E. coli/fecal coliforms), and EN/FC (enterococci/fecal coliforms) are summarized in Tables 2 and 4. The column headings are the same as Table 1 , with the log normal distribution used to summarize the variation of the bacterial indicator ratios. The FC/FS ratio has been recommended by Geldreich et al. (1969) and Geldreich $(1970,1972)$ and by Standard Methods (APHA, 1985) as an indication of origin of fecal contamination, with values greater than 4.0 suggesting human sources and a value less than 0.7 suggesting animal souces. The EC/FC ratio for the U.S. EPA recommended level of $E$. coli of 126 to the accepted fecal coliforms of 200 is 0.63 , while the EN/FC ratio for the U.S. EPA recommended level of enterococci of 33 to the accepted fecal coliforms of 200 is 0.165 . The results in Tables 2 and 4 should be viewed in relation to these levels.

No statistically significant difference $(P>0.05)$ was found between the ratios for the wet and dry

Table 2. Bacterial indicator ratios 1985

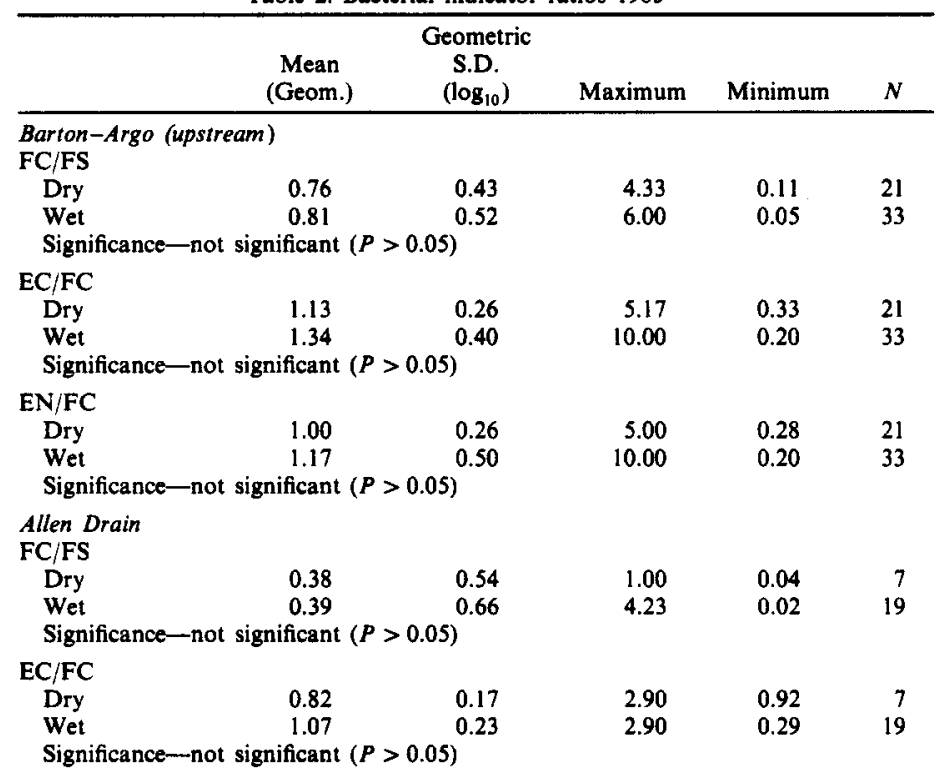


Table 2-continued

\begin{tabular}{|c|c|c|c|c|c|}
\hline & $\begin{array}{c}\text { Mean } \\
(\text { Geom. })\end{array}$ & $\begin{array}{c}\text { Geometrio } \\
\text { S.D } \\
\left(\log _{10}\right)\end{array}$ & Maximum & Minimum & $N$ \\
\hline \multicolumn{6}{|l|}{$\mathrm{EN} / \mathrm{FC}$} \\
\hline Dry & 0.80 & 0.41 & 8.00 & 0.36 & 7 \\
\hline Wet & 1.71 & 0.60 & 20.00 & 0.16 & 19 \\
\hline \multicolumn{6}{|c|}{ Significance-not significant $(P>0.05)$} \\
\hline \multicolumn{6}{|c|}{$\begin{array}{l}\text { Traver Drain } \\
\text { FC/FS }\end{array}$} \\
\hline Dry & 0.29 & 0.27 & 0.63 & 0.14 & 7 \\
\hline Wet & 0.34 & 0.32 & 0.79 & 0.11 & 10 \\
\hline \multicolumn{6}{|c|}{ Significance-not significant $(P>0.05)$} \\
\hline \multicolumn{6}{|l|}{$\mathrm{EC} / \mathrm{FC}$} \\
\hline Dry & 1.00 & 0.18 & 1.41 & 0.41 & 7 \\
\hline Wet & 0.82 & 0.18 & 1.43 & 0.42 & 10 \\
\hline \multicolumn{6}{|c|}{ Significance-not significant $(P>0.05)$} \\
\hline \multicolumn{6}{|c|}{$\mathrm{EN} / \mathrm{FC}$} \\
\hline Dry & 2.98 & 0.24 & 6.77 & 1.37 & 7 \\
\hline Wet & 1.87 & 0.50 & 9.14 & 0.27 & 10 \\
\hline \multicolumn{6}{|c|}{ Significance-not significant $(P>0.05)$} \\
\hline \multicolumn{6}{|c|}{$\begin{array}{l}\text { Fuller Drain } \\
\text { FC/FS }\end{array}$} \\
\hline Dry & 0.58 & 0.28 & 1.00 & $0.1 ?$ & 7 \\
\hline Wet & 0.53 & 0.42 & 1.03 & 0.07 & 4) \\
\hline \multicolumn{6}{|c|}{ Significance-not significant $(P>0.05)$} \\
\hline \multicolumn{6}{|l|}{$\mathrm{EC} / \mathrm{FC}$} \\
\hline Dry & 1.22 & 0.15 & 2.00 & 1.00 & 7 \\
\hline Wet & 1.08 & 0.13 & 2.00 & 0.69 & 9 \\
\hline \multicolumn{6}{|c|}{ Significance-not significant $(P>0.05)$} \\
\hline \multicolumn{6}{|l|}{$\mathrm{EN} / \mathrm{FC}$} \\
\hline Dry & 1.35 & 0.24 & 4.00 & 1.00 & 7 \\
\hline Wet & 1.54 & 0.24 & 4.00 & 1.00 & 9 \\
\hline \multicolumn{6}{|c|}{ Significance--not significant $(P>0.05)$} \\
\hline $\begin{array}{l}\text { North C } \\
\text { FC/FS }\end{array}$ & & & & & \\
\hline Dry & 0.75 & 0.11 & 1.00 & 0.49 & 7 \\
\hline Wet & 0.33 & 0.28 & 1.12 & 0.13 & 15 \\
\hline Signifi & $P=0.01 \mathrm{le}$ & & & & \\
\hline $\mathrm{EC} / \mathrm{FC}$ & & & & & \\
\hline Dry & 1.04 & 0.12 & 1.40 & 0.67 & 7 \\
\hline Wet & 0.98 & 0.21 & 2.42 & 0.36 & is \\
\hline Signifi & nificant $(P$ & $0 \$)$ & & & \\
\hline $\mathrm{EN} / \mathrm{FC}$ & & & & & \\
\hline Dry & 1.50 & 0.33 & 7.00 & 0.69 & 7 \\
\hline Wet & 2.30 & 0.29 & 6.22 & 0.63 & 15 \\
\hline Signif & nificant ( $P$ & 05) & & & \\
\hline $\begin{array}{l}\text { Gallup } F \\
\text { FC/FS }\end{array}$ & m) & & & & \\
\hline Dry & 1.53 & 0.36 & 7.22 & 0.29 & 21 \\
\hline Wet & 1.63 & 0.51 & 230.00 & 0.07 & 142 \\
\hline Signif & nificant $(P$ & $05)$ & & & \\
\hline $\mathrm{EC} F \mathrm{FC}$ & & & & & \\
\hline Dry & 0.99 & 0.20 & 2.60 & 0.33 & 21 \\
\hline Wet & 0.88 & 0.27 & 12.00 & 0.07 & 142 \\
\hline Signifi & nificant $(P$ & 05) & & & \\
\hline $\mathrm{EN} \mathbf{F C}$ & & & & & \\
\hline Dry & 0.47 & 0.40 & 1.71 & 0.07 & 21 \\
\hline Wet & 0.50 & 0.52 & 19.00 & 0.01 & 142 \\
\hline Signifi & nificant $(P$ & 05) & & & \\
\hline $\begin{array}{l}A n n A r b \\
\text { FC/FS }\end{array}$ & effluent & & & & \\
\hline Dry & 0.78 & 0.41 & 3.12 & 0.19 & 7 \\
\hline Wet & 0.86 & 1.05 & 9.50 & 0.002 & 9 \\
\hline Signifi & nificant ( $P$ & .05) & & & \\
\hline $\mathrm{EC} / \mathrm{FC}$ & & & & & \\
\hline Dry & 0.92 & 0.21 & 2.05 & 0.53 & 7 \\
\hline Wet & 1.01 & 0.14 & 2.00 & 0.63 & 9 \\
\hline Signif & nificant ( $P$ & .05) & & & \\
\hline EN/FC & & & & & \\
\hline Dry & 1.47 & 0.52 & 7.55 & 0.26 & 7 \\
\hline Wet & 0.76 & 0.47 & 4.00 & 0.11 & 9 \\
\hline Signifi & nificant $(P$ & 05) & & & \\
\hline
\end{tabular}


Table 3. Bacterial indicator organism levels, wet periods-1985. Gallup Park Stations

\begin{tabular}{|c|c|c|c|c|c|}
\hline & $\begin{array}{c}\text { Mean } \\
(\text { Geom.) } \\
\text { No. } 100 \mathrm{ml}\end{array}$ & $\begin{array}{c}\text { Geometric } \\
\text { S.D. } \\
\left(\log _{10}\right)\end{array}$ & $\begin{array}{l}\text { Maximum } \\
\text { No. } / 100 \mathrm{ml}\end{array}$ & $\begin{array}{l}\text { Minimum } \\
\text { No. } / 100 \mathrm{ml}\end{array}$ & $N$ \\
\hline \multicolumn{6}{|c|}{ Day 0 -following rain } \\
\hline Fecal coliforms & 1810 & 0.84 & 41,000 & 50 & 48 \\
\hline E. coli & 1720 & 0.76 & 34,000 & 60 & 48 \\
\hline Fecal streptococci & 1730 & 0.84 & 52,000 & 15 & 48 \\
\hline Enterococci & 1730 & 0.83 & 45,500 & 20 & 48 \\
\hline \multicolumn{6}{|c|}{ Day 1} \\
\hline Fecal coliforms & 520 & 0.62 & 16,000 & 24 & 45 \\
\hline E. coli & 430 & 0.56 & 10,000 & 30 & 45 \\
\hline Fecal streptococci & 210 & 0.84 & 24,000 & 4 & 45 \\
\hline Enterococci & 150 & 0.85 & 19,000 & 2 & 45 \\
\hline \multicolumn{6}{|c|}{ Day 2} \\
\hline Fecal coliforms & 200 & 0.48 & 1700 & 18 & 36 \\
\hline E. coli & 160 & 0.36 & 1500 & 20 & 36 \\
\hline Fecal streptococci & 94 & 0.44 & 1100 & 10 & 36 \\
\hline Enterococci & 71 & 0.53 & 700 & 6 & 36 \\
\hline
\end{tabular}

periods with the exception of the North Campus FC/FS ratio. FC/FS mean ratios for the storm drains are for the most part less than 0.7 suggesting animal rather than human origin, while the river stations and treatment plant effluent are all below the ratio of 4.0 suggestive of human sources. Schmidt and Spencer (1986) reported on finding relatively few illegal domestic discharges into Allen Drain

Particular attention was given to the Gallup Park observations because the FC/FS ratio was 1.63 , a value much higher than the upstream storm drains and river stations. Table 3 lists the indicator organism levels for the Gallup Park stations for days 0,1 and 2 , following precipitation. Also, Table 4 includes the indicator organism ratios for these same conditions. It is apparent from Table 4 that the FC/FS ratio increases from day 0 to day 1 (statistically significant at $P=0.01$ level) primarily due to the more rapid disappearance of the fecal streptococci over the fecal coliforms. These observations are consistent with the work of Geldreich and Kenner (1969). Moreover, the EN/FC ratio decreases significantly from day 0 to day 1 primarily due to the more rapid disappearance of the enterococci.

Review of the geometric mean EC/FC ratios shows them to be in the range of $0.82-1.34$, well above the ratio of 0.63 calculated using the U.S. EPA recommended level of $E$. coli. Greater variation occurs in

Table 4. Bacterial indicator organism ratios, wet periods-1985. Gallup Park stations

\begin{tabular}{|c|c|c|c|c|c|}
\hline & $\begin{array}{c}\text { Mean } \\
\text { (Geom.) }\end{array}$ & $\begin{array}{c}\text { Geometric } \\
\text { S.D. } \\
\left(\log _{10}\right)\end{array}$ & Maximum & Minimum & $N$ \\
\hline \multicolumn{6}{|c|}{ Day 0 -following rain } \\
\hline $\mathrm{FC} / \mathrm{FS}$ & 1.04 & 0.46 & 14.09 & 0.07 & 48 \\
\hline $\mathrm{EC} / \mathrm{FC}$ & 0.95 & 0.31 & 12.00 & 0.25 & 48 \\
\hline EN/FC & 0.96 & 0.48 & 19.00 & 0.08 & 48 \\
\hline \multicolumn{6}{|c|}{ Day I } \\
\hline $\mathrm{FC} / \mathrm{FS}$ & 2.46 & 0.56 & 230 & 0.13 & 45 \\
\hline $\mathrm{EC} / \mathrm{FC}$ & 0.84 & 0.18 & 2.00 & 0.29 & 45 \\
\hline $\mathrm{EN} / \mathrm{FC}$ & 0.29 & 0.50 & 2.00 & 0.007 & 45 \\
\hline \multicolumn{6}{|c|}{ Day 2} \\
\hline $\mathrm{FC} / \mathrm{FS}$ & 2.15 & 0.43 & 41.00 & 0.19 & 36 \\
\hline $\mathrm{EC} / \mathrm{FC}$ & 0.79 & 0.31 & 2.67 & 0.09 & 36 \\
\hline $\mathrm{EN} / \mathrm{FC}$ & 0.35 & 0.42 & 2.33 & 0.02 & 36 \\
\hline
\end{tabular}

this ratio for individual samples. It is recognized that $E$. coli is a subgroup of the fecal coliform group. However, each test is performed separately and independently. Thus, it is possible to have a higher $E$. coli value for a given sample as a result of variation in the testing tehniques. The U.S. EPA (1986) indicated that using the fecal coliforms at the maximum geometric mean of 200 per $1000 \mathrm{ml}$, would cause an estimated 8 illness per 1000 swimmers at fresh water beaches. They indicate that this relationship is approximate and is based on applying ratios of the geometric means of the various indicators from the EPA studies to the 200 per $100 \mathrm{ml}$ fecal coliforms criterion. The $E$. coli and enterococci criteria were developed using this currently accepted illness rate. The equations developed by Dufour (1984) were used to calculate the geometric mean indicator densities corresponding to the accepted gastrointestinal illness rates. With this background in mind and considering the results of the present study, the use of the EPA criteria of 126 organisms $/ 100 \mathrm{ml}$ of $E$. coli in the Huron River in the Ann Arbor, Michigan area would constitute a more restrictive condition than that imposed by the present level of $200 / 100 \mathrm{ml}$ of fecal coliforms. The EN/FC ratios are also well above the ratio of 0.165 calculated using the U.S. EPA recommended enterococcal level. Additional results from other areas are necessary to refine the $E$. coli and enterococci levels for water quality standard development purposes, if the intent is to maintain the currently accepted illness rate.

The U.S. EPA (1986b) as part of their proposed bacteriological ambient water quality criteria indicate the criteria are calculated as the geometric mean of a statistically sufficient number of samples, generally not less than five samples equally spaced over a thirty day period. Recommendations on bacterial criteria monitoring are included in the U.S. EPA (1986a) ambient water quality criteria for bacteria document. Sample size is a factor in a test for statistical significance, and more than the minimum of five samples may well be necessary to demonstrate statistical significance in a given case. The closer two sets of data being subjected to tests for statistical 
significance are to one another in level, the greater are the requirements for individual number of observations. A second element is the inherent variability in indicator bacteriological data.

The size of the data base which the U.S. EPA used in deriving their criteria is not readily available to the writers. Dufour (1984) summarizes bacterial indicator densities at Lake Erie, Pennsylvania bathing beaches during 1979, 1980 and 1982, and bacterial indicator densities at Keystone Lake, Oklahoma bathing beaches, 1979-1980. However, the individual number of observations for each summary has not been included.

The experimental design for the present investigation was partially dependent on precipitation levels occurring during the 1985 summer period. Tests for statistical significance were conducted on data collected under these conditions and must be interpreted in this light.

Physical-chemical observations summarized in Table 5 reflect the source of the sample, i.e. river water, storm drain or treatment plant effluent. Generally, the turbidity and suspended solids levels are higher in the drains and Gallup Park stations during wet periods as compared to dry periods. Also, the conductivity levels at these same locations are lower during wet periods, no doubt reflecting more surface discharge than ground water discharge. Data is included for the Barton-Argo (Upstream), Allen Drain, Gallup Park (Downstream), and the Ann Arbor Wastewater Treatment Plant effluent. Allen Drain is representative of the other storm drains in the area. Documentation of the physical-chemical levels in the study area is included to complement the bacteriological data.

\section{CONCLUSIONS}

(1) Wet weather bacterial indicator densities are statistically significantly higher $(P<0.05)$ than the dry weather levels at all Huron River and storm drain outlets in the Ann Arbor, Michigan area, except for the Fuller Drain and the Ann Arbor wastewater treatment plant effluent.

(2) The mean level for all bacterial organisms is statistically significantly higher $(P<0.05)$ at Gallup

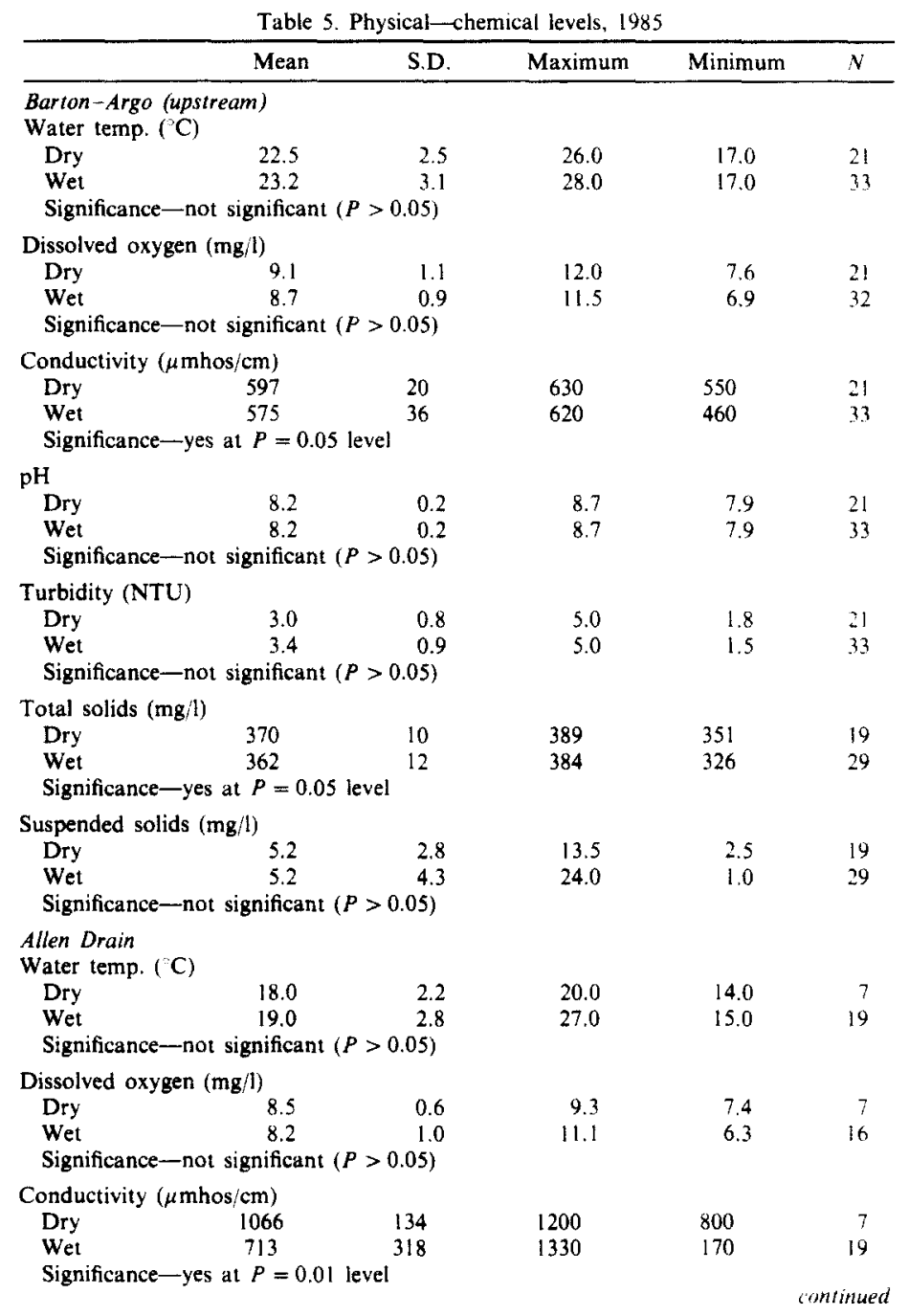


Table 5-continued

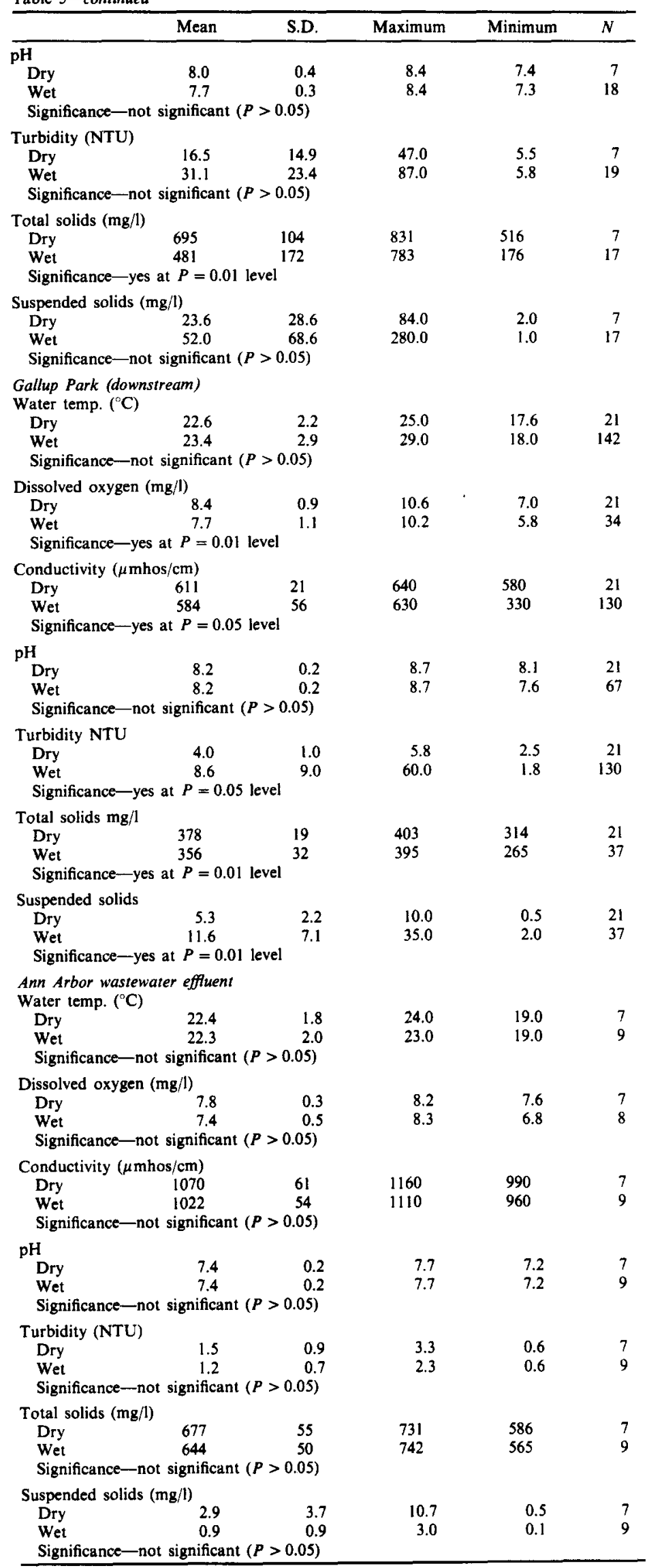


Park (downstream) than at Barton-Argo (upstream) on the Huron River, reflecting discharges from the urban storm drains.

(3) No statistical significance $(P>0.05)$ was found between the mean bacterial indicator levels at Barton-Argo (Huron River upstream) and the Ann Arbor wastewater treatment plant effluent, indicating that the storm drains rather than the wastewater treatment plant are primarily responsible for the elevated river levels.

(4) The FC/FS (fecal coliforms/fecal streptococci) ratios for the storm drains are low and suggestive of more animal than human sources.

(5) Bacterial indicator organism levels in Gallup Park (Huron River) for days 0,1 and 2 following precipitation indicate a more rapid disappearance of the fecal streptococci and enterococci than the fecal coliforms and E. coli.

(6) The geometric mean EC/FC (E. coli/fecal coliforms) ratios are in the range of $0.82-1.34$, well above the ratio of 0.63 calculated using the U.S. EPA recommended level of $E$. coli of $126 / 100 \mathrm{ml}$ to the present fecal coliform level of $200 / 100 \mathrm{ml}$. Greater variation exists in this ratio for individual samples. If the intent is to maintain the currently accepted illness rate, additional results from other area are necessary to refine the $E$. coli and enterococci levels for water quality standard development purposes.

Acknowledgements-Financial support was provided by the City of Ann Arbor and Washtenaw County, Michigan. Particular recognition is given to James E. Murray, Washtenaw County Drain Commissioner, for his encouragement and support.

\section{REFERENCES}

APHA (1985) Standard Methods for the Examination of Water and Wastewater, 16th edition. American Public Health Association, Washington, D.C.

Benzie W. J. and Courchaine R. J. (1966) Discharges from separate storm sewers and combined sewers. J. Wat. Pollut. Control Fed. 38, 410-421.

Burm R. J, and Vaughan R. D. (1966) Bacteriological comparison between combined and separate sewer discharges in Southeastern Michigan. J. Wat. Pollut. Control Fed. 38, 400-409.

Cabelli V. J. (1983) Health effects criteria for marine recreational waters. EPA600/1-80-031, U.S.EPA, Research Triangle Park, N.C.

Collins P. G. and Ridgeway J. W. (1980) Urban storm runoff quality in southeast Michigan. J. envir. Engng Div., Proc. Am. Soc. civ. Engs 106(EE1), 153-162.

Dufour A. P. (1984) Health effects criteria for fresh recreational waters. EPA600/1-84-004, U.S. EPA, Research Triangle Park, N.C.
Dufour A. P., Strickland E. R. and Cabelli V. J. (1981) Membrane filter method for enumerating Escherichi coli. Appl. envir. Microbiol. 41, 1152-1158.

Foster D. H., Hanes N. B. and Lord S. M. (1971) A critical examination of bathing water quality standards. $J$. Wat. Pollut. Control Fed. 43, 2229.

Fox D. J. and Guire K. E. (1976) Documentation for MIDAS, 3rd edition. Statistical Research Laboratory, The University of Michigan, Ann Arbor, Mich.

Gannon J. J. (1959) Statistical basis for interpretation of data. Proceedings of the Michigan Sewage and Industrial Wastes Association.

Gannon J. J. (1988) Managing short-term urban stormwater effects. Wat./Engng Mgmi 135, 25.

Geldreich E. E. (1970) Applying bacteriological parameters to recreational water quality. J. Am. Wat. Wks Assoc. 62 $113-120$.

Geldreich E. E. (1972) Buffalo Lake recreational water quality: a study in bacteriological data interpretation. Wat. Res. 6, 913-924.

Geldreich E. E., Best L. C., Kenner B. A. and VanDonsel D. J. (1968) The bacteriological aspects of stormwater pollution. J. Wat. Pollut. Control Fed. 40, 1861-1872.

Geldreich E. E. and Kenner B. A. (1969) Concepts of fecal streptococci in stream pollution. $J$. Wat. Pollut. Control Fed. 41, R336-R352.

Henderson J. M. (1968) Enteric disease criteria for recreational waters. J. sanit. Engng Div., Proc. Am. Soc. civ. Engng 94, 1253-1276

Levin M. A., Fischer J. R. and Cabelli V. J. (1975) Membrane filter technique for enumeration of enterococci in marine waters. Appl. Microbiol. 30, 66-71.

Olivieri V. P. (1977) Microorganisms in urban stormwater EPA-600/2-77-087, U.S. EPA, Cincinnati, Ohio.

Schillinger J. E. and Gannon J. J. (1985) Bacterial adsorption and suspended particles in urban stormwater. $J$. Wat. Pollut. Control Fed. 57, 384-389.

Schmidt S. D. and Spencer D. R. (1986) The magnitude of improper waste discharges in an urban stormwater system. J. Wat. Pollut. Control Fed. 58, 744-748.

Statistical Research Laboratory (1976) Elementary Statistics Using MIDAS. The University of Michigan, Ann Arbor, Mich.

U.S. Environmental Protection Agency (EPA) (1985) Test methods for Escherichia coli and enterococci. EPA-600/ 4-85/076. U.S. EPA, Cincinnati, Ohio.

U.S. Environmental Protection Agency (EPA) (1986a) Ambient Water Quality Criteria for Bacteria EPA440/ 5-84-002, U.S. EPA, Washington, D.C.

U.S. Environmental Protection Agency (EPA) (1986b) Bacteriological ambient water quality criteria; availability. Federal Register, 51, 8012.

Vasconcelos G. J. and Anthony N. C. (1985) Microbiological quality of recreational waters in the Pacific Northwest. J. Wat. Pollut. Control Fed. 57, 366-377.

Velz C. J. (1984) Applied Stream Sanitation, 2nd edition. Wiley, New York.

Washtenaw County Mich. (1981) Controlling Urban Stormwater Runoff in Washtenaw County. Washtenaw County Drainage Board and Southeast Michigan Council of Governments, Detroit, Mich. 